\title{
EVALUASI KINERJA KARYAWAN PANEN PADA PRODUKSI KELAPA SAWIT DI PT. TELEN BUKIT PERMATA ESTATE
}

\section{PERFORMANCE EVALUATION OF HARVEST EMPLOYEES IN OIL PALM PRODUCTION PT. TELLEN HILS GEM STATE}

\author{
Nanli Artin ${ }^{\star 1}$, Roby $^{1}$, Daryono ${ }^{1}$ \\ ${ }^{1}$ Politeknik Pertanian Negeri Samarinda, Kampus Gunung Panjang, Jl. Samratulangi, \\ Samarinda, Indonesia \\ nanlinoro@gmail.com
}

\begin{abstract}
This research is motivated by the importance of evaluating harvest employees in oil palm production, both in the industrial and organizational fields. This study analyzes the performance of harvest employees at PT. Telen Bukit Permata Estate, particularly in the palm oil harvesting sector. Therefore, a company must be able to manage its human resources properly in order to increase productivity in the company.

This study aims to identify the characteristics of harvest employees and to evaluate the performance of harvest employees on oil palm production, based on gender, age, education and length of work. This research was conducted at PT. Telen Bukit Permata Estate in Kaubun District, East Kutai Regency. This research is focused on harvest employees who are at PT. Telen Bukit Permata Estate. This research was conducted with a descriptive method. The results of the observations made were that the average score of the questionnaire was $75.77 \%$. Where based on the weighting scale it is included in the tofu / frequent category.
\end{abstract}

Keywords : employee performance, productions, characteristics

\section{PENDAHULUAN}

Kelapa Sawit (Elaeis Guineensis Jacq) merupakan tanaman penghasil minyak nabati yang paling produktif dibandingkan dengan seluruh tanaman penghasil minyak nabati lainnya. Menurut (Sunarko, 2014) Potensi tanama kelapa sawit selama 25 tahun dengan manajemen tanaman yang baik, rata rata produktivitasnya dapat mencapai 18 ton TBS/tahun, bahkan lebih banyak. tergantung dari qualitas benih dan kelas lahan, serta manajemen produksi, khususnya teknik budi daya yang diterapkan(Risza,1994) Kelapa sawit merupakan kontributor yang sangat penting bagi ekonomi indonesia. Indonesia merupakan penghasil minyak kelapa sawit terbesar di dunia. Perkebunan kelapa sawit terbesar berada di daerah Sumatra dan Kalimantan.

Kinerja seseorang sudah ditentukan dalam bentuk standar kerja perusahaan menurut jenis pekerjaannya. Apabila sebagian besar karyawan bekerja sesuai dengan standar perusahaan, maka tidak menjadi masalah. Sebaliknya, jika

karyawan bekerja di bawah standar maka beban kerja yang diemban berlebih. Sementara jika karyawan bekerja di atas standar, dapat berarti estimasi standar yang ditetapkan lebih rendah dibanding kapasitas karyawan itu sendiri. Kemudian hal itu diterjemahkan dalam bentuk lamanya (jam dan hari) karyawan yang diperlukan untuk mencapai output tersebut, sehingga dapat diketahui pada jenis pekerjaan apa saja yang terjadi deviasi negatif atau sesuai standar. (Novera, 2010).

Dalam suatu sistem operasi perusahaan, potensi sumber daya manusia pada hakekatnya merupakan salah satu modal dan memegang suatu peran yang paling penting dalam mencapai tujuan perusahaan. Oleh karena itu perusahaan perlu mengelola sumber daya manusia sebaik mungkin. Begitu juga untuk menghadapi persaingan saat ini, perusahaan harus 
mampu memiliki sumber daya manusia yang berkualitas. Sumber daya manusia merupakan aspek yang krusial untuk menunjang produktivitas sebuah perusahaan agar mampu bertahan di dalam ketatnya persaingan perusahaan saat ini.

\section{METODOLOGI}

\section{Metode Pengambilan Data}

Teknik pengumpulan data yang dipakai dalam penelitian ini adalah :

1. Data primer yaitu data yang diperoleh melalui kegiatan pengumpulan data langsung di lokasi penelitian atau di lapangan. Dalam membagikan kosener dan Tanya jawab pada karyawan panen.

2. Data sekunder yaitu data yang diperoleh tidak secara langsung oleh peneliti dari subjek penelitiaannya. Data tersebut meliputi jumlah tenaga kerja 18 pemanen, masa kerja tenaga kerja pemanen, dan SOP pemanenan tanaman kelapa sawit.

\section{Prosedur Penelitian}

1. Persiapan

Persiapan yang dilakukan sebelum melakukan penelitian ada beberapa tahapan persiapan yaitu :

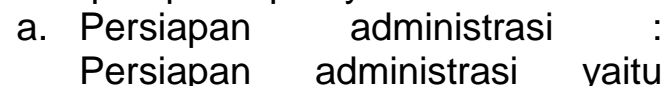
pembuatan proposal, surat terkait masalah perijinan dalam melakukan sebuah penelitian, dan menyusun rencana kerja.

b. Orientasi lapangan : Orientasi lapangan untuk mengetahui lokasi kerja, jumlah tenaga kerja dan juga untuk menentukan sampel penelitian.

c. Sampel : Sampel dalam penelitian ini di ambil minimal 20 responden dari objek penelitian (disesuaikan kondisi di lapangan).

d. Pengambilan data : Pengambilan data pada penelitian ini menggunakan kuisoner untuk memperoleh data kinerja karyawan panen pada produksi sawit.

e. Analisis data : Analisis data yang digunakan dalam penelitian ini adalah analisis deskriptif menurut sugyono ( 2008), analisis deskriptif adalah penelitian yang dilakukan untuk mengetahui nilai variabel mandiri, baik satu variable 19 atau lebih (independen) tanpa membuat perbandingan atau menghubungkan dengan variabel yang lain. Kualitatif adalah sebuah penelitian riset yang sifatnya deskriptif, cenderung menggunakan analisis dan menampakkan proses maknanya. Kuantitatif merupakan salah satu jenis penelitian yang lebih sistematis, spesifik, terstruktur dan juga terencana hingga mendapatkan sebuah kesimpulan.

Teknik penentuan persentase dari jumlah jawaban pertanyaan Menurut sugiyino (2012), untuk mengetahui jumlah jawaban dari para responden melalui presentase yaitu di gunakan rumus sebagai berikut :

$P=f n \times 100 \%$

Keterangan:

$$
\begin{array}{ll}
\mathrm{P} & =\text { persentase } \\
\mathrm{F} & =\text { jumlah dari setiap pertanyaan } \\
\mathrm{n} & =\text { jumlah skor ideal } \\
100 \% & =\text { bilangan tetap }
\end{array}
$$

\section{HASIL DAN PEMBAHASAN}

Berdasarkan data dari 20 responden yaitu karyawan panen pada tanaman kelapa sawit dari daftar pertanyaan didapatkan karateristik responden mengenai jenis kelamin, umur, pendidikan dan lama bekerja.

a. Jenis kelamin

Berdasarkan hasil penelitian diperoleh data jenis kelamin karyawan panen $100 \%$ adalah laki-laki. Hal ini diduga dengan kenyataan di lapangan karena semua karyawan panen adalah laki-laki, memanen buah kelapa sawit merupakan pekerjaan yang berat membutuhkan kekuatan tangan yang kuat dan teknik dalam memegang alat panen tersebut. Mulai dari proses memotong buah atau menurunkan buah kelapa sawit, memotong pelapah, mengutip brondolan dan menaruh buah 
kelapa sawit ke dalam angkong sampai membawanya menuju TPH. Hal ini didukung menurut Sarwono (2007) bahwa, dengan bekerja mencari nafkah masih didominasi laki-laki sebagai kepala keluarga, untuk pekerjaan rumah didominasi perempuan. Menurut fakhi (1999) menyatakan bahwa, ciri - ciri dari sifat gender bahwa perempuan dikenal dengan lemah lembut, cantik, emosional dan keibuan. Sementara laki-laki dianggap kuat rasional jantan dan perkasa.

b. Umur

Berdasarkan umur pada karyawan panen PT.Telen Bukit Permata Mill berada antara usia 31 sampai 55 tahun. Hal ini di duga karena umur 31- 55 termasuk dalam usia produktif, dengan mempumyai banyak pengalaman akan menambah pengetahuan mereka sendiri walaupun secara fisik tidak semaksimal seperti waktu berumur 20 tahun. Tetapi umur tidak menjadi hambatan bagi mereka untuk mencapai target yang telah ditentukan oleh perusahaan. Hal ini didukung menurut sugiharsono dkk (2008) bahwa, penduduk usia produktif adalah penduduk pada kelompok usia di mana ia dapat berpenghasilan untuk mencukupi kebutuhan hidupnya, yaitu antara usia 15-64 tahun.

Hal ini didukung menurut lqbal (2006) bahwa, dengan semakin bertambahnya usia maka produktivitasnya ikut menurun, hal ini disebabkan keterampilan fisik akan berkurang seiring pertumbuhan usia tetapi pengalaman dan kematangan jiwa akan meningkat.

c. Pendidikan

Berdasarkan hasil penelitian pendidikan pada karyawan panen PT. Telen Bukit Permata Mill berada pada tingkat SMP. Hal ini diduga dalam kegiata panen pendidikan tidak berpengaruh karena lebih mengandalkan tenaga (fisik). Walaupun pendidikan meraka rendah tetapi segi pengalaman mereka lebih banyak mengerti dan paham dari kita yang berpendidikan tinggi karena mereka sudah terbiasa dengan aktifitas yang mereka jalani setiap harinya. Hal ini didukung Hasibuan (2007) bahwa, pendidikan meliputi pengetahuan dan pengalaman yang disusun secara logis sistematis mengenai kegiatan-kegiatan dan usaha-usaha yang dijalankan dengan tujuan mengubah tingkah laku manusia kearah yang diinginkan. Menurut Mubarak (2012) bahwa, pendidikan adalah suatu usaha untuk mengembangkan kepribadian dan kemampuan di dalam dan di luar sekolah dan berlangsung seumur hidup. Pendidikan mempengaruhi proses belajar, makin tinggi pendidikan seseoang makin mudah seseorang tersebt memperoleh informasi. Pendidikan yang minim maka kesulitannya adalah berkomunikasi. Sehingga untuk berkomunikasi dan bertanya dengan menggunakan bahasa informal dan tidak baku. Cara lain-lain untuk berkomunikasi dengan mereka adalah dengan bercerita. Degan begitu lebih banyak cerita peneliti ambil dari mereka karena mereka dapat berbagi apa yang yang dirasakan selama bekerja. d. Lama bekerja

Berdasarkan hasil penelitian lama bekerja pada karyawan panen PT. wira inova nusantara berkisar 7 sampai dengan 10 tahun. Hal ini diduga karena pada saat melakukan pertanyaan dan wawancara mereka menjawab dengan panjang lebar menceritakan apa yang mereka lakukan hari ini, aktivitas setiap harinya dan apa yang dialami selama bekerja karena

pengalaman mereka lebih banyak bila dibandingkan dengan yang kurang 1 tahun bekerja lebih sedikit informasi yang didapat. Pengalaman adalah guru yang paling baik. Hal ini didukung Menurut Faizin dan Winarsi (2008) bahwa, dengan lama bekerja merupakan komponen yang terdiri dari usia, masa kerja dan golongan kepangkatan. Secara keseluruhan dapat disimpulkan masa kerja merupakan tenggang waktu yang digunakan seorang karyawan untuk menyumbangkan tenaganya pada perusahaan sehingga akan menghasilkan sikap kerja dan keterampilan kerja yang berkualitas. Menurut Sastrohadiwiryo (2001) bahwa, hal ini sejalan dengan bertambahnya pekerjaan maka akan semakin bertambah pula pengetahuan dan 
keterampilan seseorang dalam bekerja. Hal tersebut dapat dipahami karena terlatih dan sering mengulang suatu pekerjaan sehingga kecakapan dan keterampilan semakin dikuasai secara mudah.

e. Hasl skor kuesoner

Tingkat kinerja karyawan panen kelapa sawit terhadap produksi menunjukkan bahwa hasil perhitungan masuk kategori (tahu/sering) hal ini diduga karena berdasarkan persentase tingkat pendidikan mayoritas adalah SMP yaitu $80 \%$. sehingga diduga tingkat pendidikan yang rendah itu pengetahuan mereka terhadap pemahaman tentang kinerja. Hal ini didukung oleh pendapat Tirtarahardja (2005), menyatakan bahwa tingkat pendidikan dapat mempengaruhi kemampuan dan perkembangan seseorang secara berkesinambungan. Menurut Hariandja (2002), menyatakan bahwa tingkat pendidikan seorang karyawan mampu meningkatkan daya saing perusahaan dan memperbaiki kinerja perusahaan. selain itu, karakteristik responden berdasarkan umur meskipun masih tergolong produktif tetapi usia mereka sudah mencapai 4155 tahun. Pada usia ini untuk daya pemahaman, daya ingat, dan bahkan daya berfikir mereka sudah mulai menurun. Menurut pendapat Notoatmodjo (2003), bahwa semakin bertambah umur akan semakin berkembang pula daya tangkap dan pola pikirnya, sehingga pengetahuan yang diperoleh semakin banyak. Sedangkan menurut Huclok (1998), menyatakan bahwa semakin cukup umur, tingkat kematangan dan kekuatan seseorang akan lebih matang dalam berfikir dan bekerja. Sedangkan lama bekerja persentase $60 \%$ dengan lama bekerja antara 7 - 10 tahun, tetapi pengalaman mereka hanya terbatas sebagai karyawan panen.

\section{KESIMPULAN}

1. Identitas responden meliputi jenis kelamin karyawan panen $100 \%$ lakilaki, umur antara usia 41 sampai 55 tahun, pendidikan rata-rata pada tingkat SMP dan lama bekerja pada karyawan panen PT.Telen Bukit Permata estate berkisar 1 sampai dengan 10 tahun.

2. Evaluasi mengenai kinerja menunjukkan sebesar $75,77 \%$ masuk dalam kategori (tahu/sering).

\section{DAFTAR PUSTAKA}

Sunarko. 2014. Budi Daya Kelapa Sawit Di Berbagai Jenis Lahan. Jakarta : PT AgroMedia Pustaka. 19 hal

Risza. S. 1994. Kelapa Sawit Upaya Peningkatan Produktivitas. Yogyakarta : Penerbit Kansius Joefly. 2013 ketua umum gabungan pengusaha sawit indonesa (GAPKI) indonesa pemasok minyak kelapa sawit terbesar di dunia.

Novera. W. 2010. Analisis Beban Kerja Dan Kebutuhan Karyawan Bagian Administrasi Akademik Dan Kemahasiswaan (Studi Kasus Unit Tata Usaha Departemen Pada Institut Pertanian Bogor). [Skripsi]. Bogor: (ID): Institut Pertanian Bogor.

Wirawan. (2009). Evaluasi Kinerja Sumber Daya Manusia. Jakarta: Salemba

Hasibuan. Malayu P. (2001). Manajemen Sumber Daya Manusia. Jakarta: PT Bumi Aksara.

Mangkuprawira, Sjafri dan Hubeis, Aida Vitayala. (2007). Manajemen Mutu sumber Daya Manusia Cetakan Pertama. Bogor: Ghalia Indonesia.

Mangkunegara, Anwar Prabu. (2000). Manajemen Sumber Daya Manusia .

Mahmudi. (2010). Manajemen Kinerja Sektor Publik. Cetakan Pertama. Yogyakarta BPFT

Grifin, R.W. (2003). Manajamen. Jakarta. Erlangga.

Kurnia aji widyatmoko. (April 2013) pemanenan atau pemotongan tandan buah segar 
Sofyandi dan Garnifa. (2007). Perilaku Organisasional. Edisi Pertama. Graha Ilmu. Moenir, H.A.S. 2004. Manajemen Pelayanan Umum di Indonesia. Jakarta: Bumi Aksara. Sarwono, P. (2007). Ilmu Bedah Kebidanan. Bina Pustaka. Banten $: 31$

Faizin dan Winarsih. (2008). Hubungan Tingkat Pendidikan dan Lama
Kerja Perawat dan Kinerja Perawat di RSU Padan Arang Kabupaten Boyolali. Berita IImu Keperawatan.

Sastrohadiwiryo, S. (2001). Manajemen

Tenaga Kerja Indonesia

Pendekatan Administrasi Dan Operasional. Jakarta. 